Современное распространение травяной (Rana temporaria) и остромордой (R. arvalis) лягушек

\title{
Present distribution of the common frog, Rana temporaria and the moor frog, $R$. arvalis (Amphibia, Anura) in the "old" Moscow
}

\author{
A. B. Petrovskiy ${ }^{1,2}$, A. A. Shpagina ${ }^{1}$, A. A. Kidov ${ }^{1 凶}$ \\ ${ }^{1}$ Russian State Agrarian University-Timiryazev Moscow Agricultural Academy \\ 49 Timiryazevskaya St., Moscow 127550, Russia \\ ${ }^{2}$ A. N. Severtsov Institute of Ecology and Evolution, Russian Academy of Sciences \\ 33 Leninsky Prosp., Moscow 119071, Russia
}

\section{Article info}

Short Communication

https://doi.org/10.18500/1814-6090-2021-21$1-2-55-62$

Received 23 February 2021, revised 16 March 2021, accepted 25 March 2021
This article is an open access article distributed under the terms and conditions of the Creative Commons Attribution 4.0 License

\begin{abstract}
The common frog (Rana temporaria) and the moor frog ( $R$. arvalis) lived in all green areas of Moscow until the end of the $20^{\text {th }}$ century. The reduction in the area of woody vegetation, the destruction of breeding sites and introduction of the invasive fish Perccottus glenii contributed to the extinction of these amphibians in most of the city. The paper provides information on the distribution of brown frogs in Moscow based on the results of monitoring in 2020. R. temporaria was found in 37 localities in the Northwestern (6 points), Northern ( 3 points), Northeastern (1 point), Eastern (9 points), Southeastern (1 point), Southern (5 points), Southwestern (5 points) and Western ( 7 points) administrative districts. Eleven finds $(29.7 \%)$ are located outside of specially protected natural areas. Most of the species' habitats (30 points, or $81.1 \%$ ) are isolated from other populations. $R$. arvalis was found in 14 localities in the Northwestern (3 points), Northern (3 points), Eastern (4 points), Southwestern (1 point) and Western (3 points) administrative districts of Moscow. Of all the finds noted, three ones $(21.4 \%)$ are located outside of specially protected natural areas. The vast majority of the habitats of the species (10 points, or $71.4 \%$ ) are isolated.
\end{abstract}

Keywords: tailless amphibians, brown frogs, European towns, urbanized territories, monitoring, conservation perspectives

For citation: Petrovskiy A. B., Shpagina A. A., Kidov A. A. Present distribution of the common frog, Rana temporaria and the moor frog, R. arvalis (Amphibia, Anura) in the "old" Moscow. Current Studies in Herpetology, 2021, vol. 21, iss. 1-2, pp. 55-62 (in Russian). https://doi.org/ 10.18500/1814-6090-2021-21-1-2-55-62

\section{REFERENCES}

Bannikov A. G., Isakov Y. A. On amphibians in Moscow city. In: Zhivotnoe naselenie Moskvy $i$ Podmoskov'ia, ego izuchenie, okhrana i napravlennoe preobrazovanie [Animal Population of Moscow and Moscow Region, Its Study, Protection and Directed Transformation]. Moscow, Institut geografii AN SSSR Publ., 1967, pp. $92-96$ (in Russian).

Bondarenko D. N., Starkov V. G. Distribution and ecology of the common snake, Natrix natrix, in Moscow and in the south of the region. In: Zemnovodnye $i$ presmykayu-shchiesya Moscovskoy oblasti [Amphibia and Reptilia of Moscow Region]. Moscow, Nauka Publ., 1989, pp. 40-43 (in Russian).

Voitekhov M. Ya., Leshcheva T. S., Flint V. E., Formozov N. A., Garushyants K. Yu. A short note about amphibian and reptile fauna of Moscow and Moscow province. In: Zemnovodnye $i$ presmykayu-shchiesya
Moscovskoy oblasti [Amphibia and Reptilia of Moscow Region]. Moscow, Nauka Publ., 1989, pp. 43-48 (in Russian).

Dunayev E. A., Kharitonov N. P. Ecological notes on the fauna of amphibians and reptiles of the Moscow region. In: Zemnovodnye i presmykayu-shchiesya Moscovskoy oblasti [Amphibia and Reptilia of Moscow Region]. Moscow, Nauka Publ., 1989, pp. 25-37 (in Russian).

Kidov A. A., Petrovskiy A. B., Shpagina A. A., Stepankova I. V. Modern distribution of the smooth (Lissotriton vulgaris) and crested (Triturus cristatus) newts in "Old" Moscow and perspectives of their conservation. Ekosistemy, 2021. iss. 25, pp. 114-124 (in Russian).

Kuznetsov B. A. About the food composition of the gray frog Rana temporaria. Russkij gidrobiologicheskij zhurnal, 1926, vol. 5, no. 1-2, pp. 26-29 (in Russian).

Kuzmin S. L. Amphibians of the Former USSR. Moscow, KMK Scientific Press Ltd., 2012. 370 p. (in Russian).

\footnotetext{
${ }^{\square}$ Corresponding author. Department of Zoology of the Institute of Zootechnics and Biology, Russian State Agrarian University -Timiryazev Moscow Agricultural Academy, Russia.

ORCID and e-mail addresses: Andrey B. Petrovskiy: https://orcid.org/0000-0003-1866-1379, meph@bk.ru; Anastasiya A. Shpagina: https://orcid.org/0000-0003-3582-3958, stasiashpagina@gmail.com; Artem A. Kidov: https://orcid.org/0000-0001-9328-2470,kidov_a@mail.ru.
} 
Lazareva N. S., Semenov D. V. To inventory of natural elements of vertebrate fauna of the Botanical Garden of Moscow State University "Aptekarskiy Ogorod". Materialy po flore i faune Respubliki Bashkortostan, 2018, vol. 19, pp. 115-131 (in Russian).

Leontyeva O. A. Trophic relationships of tailless amphibians in natural and anthropogenic landscapes of the Moscow region. In: Zhivotny mir Evropeyskoy chasti Rossii, ego izuchenie, ispol'zovanie $i$ ohrana [The Fauna of the European Part of Russia and Its Study, Use and Protection]. Moscow, Moskovskii oblastnoi pedagogicheskii institut Publ., 1991, pp. 98-110 (in Russian).

Makeeva V. M., Belokon M. M., Malyuchenko O. P., Leont'eva O. A. Evaluation of the state of the gene pool of natural populations dwelling in the fragmented landscape of Moscow and Moscow region (with special reference to brown frogs). Russian Journal of Genetics, 2006, vol. 42, no. 5, pp. 505-517.

Murkina N. V. The Status of the Amphibian Fauna of Moscow and Moscow Region in Relation to Anthropogenic Influences]. In: Zemnovodnye $i$ presmykayushchiesya Moscovskoy oblasti [Amphibia and Reptilia of Moscow Region]. Moscow, Nauka Publ., 1989, pp. 8184 (in Russian).

Petrovskiy A. B., Afrin K. A., Stepankova I. V., Shpagina A. A., Kidov A. A. On the distribution of the European common spadefoot, Pelobates fuscus (Pelobatidae, Amphibia) in Moscow. Current Studies in Herpetology, 2020, vol. 20, iss. 3-4, pp. 168-173 (in Russian). https://doi.org/10.18500/1814-6090-2020-20-3-4168-173

Pchelkin A. V., Pchelkina T. A. The influence of pollutants and climatic anomalies on the fauna of reptiles and amphibians in the Moscow region. In: Obzor sostoyaniya $i$ zagryazneniya okruzhayushchey sredy $v$ Rossijskoj Federacii za $2011 \mathrm{~g}$ [Review of the State and Pollution of the Environment in the Russian Federation in 2011]. Moscow, Rosgidromet Publ., 2012, pp. 190-192 (in Russian).

Samoylov B. L., Morozova G. V. European common frog, Rana temporaria (Linnaeus, 1758). In: The Red Data Book of the Moscow. Moscow, Departament prirodopol'zovaniia i okhrany okruzhaiushchei sredy goroda Moskvy Publ., 2011 a, pp. 277-281 (in Russian).

Samoylov B. L., Morozova G. V. The moor frog, Rana arvalis (Nilsson, 1842). In: The Red Data Book of the Moscow. Moscow, Departament prirodopol'zovaniia i okhrany okruzhaiushchei sredy goroda Moskvy Publ., 2011 b, pp. 281-283 (in Russian).

Severtsova E. A., Severtsov A. S. Comparison of variability of Rana temporaria (Amphibia, Anura) gastrula from different populations developing under the conditions of antropogenic pollution. Russian Journal of Developmental Biology, 2005, vol. 36, iss. 2, pp. 82-93.

Severtsova E. A., Severtsov A. S. Crucial stages of embryogenesis of Rana arvalis: Part 2. Development of head structures. Russian Journal of Developmental Biology, 2012, vol. 43, iss. 3, pp. 164-171.

Sevetsova E. A., Kormilitsin A. A., Severtsov A. S. Influence of anthropogenic factors on the reproduction of grass (Rana temporaria) and moor (Rana arvalis) frogs. Zoologicheskii zhurnal, 2015, vol. 94, no. 2, pp. 192-203 (in Russian).

Semenov D. V., Leontyeva O. About the State of Moscow's Herpetofauna. In: Zemnovodnye i presmykayushchiesya Moscovskoy oblasti [Amphibia and Reptilia of Moscow Region]. Moscow, Nauka Publ., 1989, pp. 60-70 (in Russian).

Stepankova I. V., Kidov A. A. Results of the amphibians fauna inventory in the Forest experimental station of Timiryazev academy (Moscow). University Proceedings. Volga Region. Natural Sciences, 2019, no. 4 (28), pp. 61-70 (in Russian). https://doi.org/10.21685/ 2307-9150-2019-4-6

Stepankova I. V., Afrin K. A., Ivolga R. A., Kidova A. A., Kidov A. A. Reproductive characteristics of Lissotriton vulgaris (Linnaeus, 1758) in Old and New Moscow. Proceedings of Gorsky State Agrarian University, $2020 a$, vol. 57, no. 1, pp. 170-175 (in Russian).

Stepankova I. V., Afrin K. A., Ivolga R. A., Kidov A. A. Comparative characteristics of morphometric and reproductive parameters of the common brown frog, Rana temporaria (Amphibia, Ranidae) from the populations of Old and New Moscow. Current Studies in Herpetology, 2020 b, vol. 20, iss. 1-2, pp. 53-60 (in Russian). https://doi.org/10.18500/1814-6090-2020-20-1-2-53-60

Terentjev P. V. Ocherk zemnovodnykh (Amphibia) Moskovskoy gubernii: rukovodstvo dlya prepodavateley [Study of Amphibians (Amphibia) Moscow Province: Guide for Lecturers]. Moscow, Gosudarstvennoe izdatelstvo, 1924.98 p. (in Russian).

Kuzmin S. L., Bobrov V. V., Dunaev E. A. Amphibians of Moscow Province: Distribution, ecology, and conservation. Zeitschrift für Feldherpetologie, 1996, Bd. 3, S. 19-72. 